УДК: 378+616-056.2-027.2+612.8+37.091.212

DOI: $10.15587 / 2519-8025.2017 .109302$

\title{
GENERAL FUNCTIONAL STATE OF THE CENTRAL NERVOUS SYSTEM OF THE FIRST ANA SECOND YEAR STUDENTS OF THE PHYSICAL EDUCATION FACULTY
}

\section{(C) A. Bosenco, M. Topchii}

Проведено дослідження динаміки функиіонального стану цеентральної нервової системи студентів молодших курсів факультету фізичного виховання за результатами простої зорово-рухової реакції під впливом дозованого фізичного велоергометричного навантаження за замкнутим ииклом (з реверсом). Встановлено два основні типи реакцій загального функиіонального стану мозку юнаків, які характеризуються різними спрямованістю, глибиною зрушень та кількісним їх співвідношенням

Ключові слова: зорово-рухова реакція, функціональний рівень системи, стійкість реакції, рівень функціональних можливостей

\section{Introduction}

Adaptation mechanisms attract attention of many researchers, because the main factor that determines the success of the activity and human health status is the effectiveness of adaptive processes $[1,2]$.

The one of objects for the study of adaptation processes is the student youth. The question of students' adaptation is an important direction of labor physiology, physical education and sport physiology, age physiology. At that studied processes are the important factors of the external environment that influence adaptation.

Adaptation to the study at higher school takes place under the influence of the complex of specific factors that cause the essential strain of regulatory systems of the organism and is a multi-level process, accompanied by socio-psychophysiological and physiological reactions [3, 4]. Under these conditions is registered the unequal degree of the strain of regulatory systems of the organism at different study stages, connected with "critical periods" of students' life. These periods are divided in the primary (first and second years) and final (pre- and graduate years) ones $[4,5]$.

\section{Literary review}

The central nervous system (CNS), due to its multi-level construction, combines all structure components into a single whole, coordinating their specific activity in the composition of integral homeostatic and behavior functional systems [6].

The question of the study and evaluation of the human central nervous system functional state by the speed of sensomotor reactions is topical for today. Determining the informativity of this parameter, it must be noted, that characteristics of motor reactions are used in two directions at the modern stage: to estimate the functional state of the central nervous system, its excitability, reactivity and mobility, and also to study individualtypological properties of the higher nervous activity, especially, intensity, balance of nervous processes [3]. The CNS functional state is used to be determined by parameters of its correspondent reactions.

The study of the students' central nervous system functional state is realized by many scientists. It is used to think, that the functional state, needed for a difficult intellectual activity is formed faster by persons with the high functional mobility of nervous processes in the cen- tral nervous system [3]. But it must be taken into account that the results of obtained parameters (system functional level, reaction stability, functional possibilities level) depend on the way of registration of the visual-motor reaction latent period [7]. It is also demonstrated, that the support of the high level of the nervous system functioning in teenagers is connected with the high psychoemotional strain [8]. At the study of organism adaptation of first year students' with a different body mass to the educational process, it was revealed, that CNS adaptation was accompanied by the growth of the information processing speed. But in girls with an insufficient or excessive body mass was observed the decrease of CNS excitability as opposite to ones with a normal mass [9].

So, data about features of students', schoolchildren' and adults' CNS functioning are present in the literature. But, to the regret, there are no enough publications, devoted to the assessment of the general functional state of the brain at dosed physical loads with intensity changes by the closed cycle.

\section{Aim and tasks of research}

The aim of the research - to study the dynamics of the general functional state of the central nervous system of first years students of the physical education faculty under the influence of physical loads by the closed cycle.

The following tasks were set for attaining this aim:

1. To determine parameters of the general functional state of the central nervous system of first and second year students of the physical education faculty in the state of the relative muscular rest.

2. To realize the comparative characteristic of the general functional state of the central nervous system of first and second year students at the fifth minutes of restoration after a physical load.

3. To study methodical approaches as to the assessment of the level of the general functional state of the human brain.

\section{Materials and methods of research}

The study was realized in the laboratory of age sport physiology, named after the professor T.M. Tsoneva at the department of biology and health bases. The topic of the research is included to the theme of the scientific work of the department "Adaptation of children 
and youth to educational and physical loads", the number of state registration $0114 \mathrm{U} 007158$.

There were examined 175 students of the first and second years of the physical education faculty by the following methods: polling, anthropophysiometry, dynamometry, testing by a dosed physical load by the close cycle (with a reversion) and statistical analysis of data.

The determination of the general functional state (GFS) of the brain was realized by reflexometry, by data of a simple visual-motor reaction registration, by T.D. Loskutova's method [10].

The method is grounded on the analysis of the statistical distribution of the repeatedly measured time of a simple visual-motor reaction and is a quantitative characteristic of the functional state of the central nervous system. According to the data of the totality of reaction time values, the variation curve that allows to determine the following parameters, is built:

- Tmod - most often time reaction value, in seconds (s);

- Pmax - maximal probability that corresponds to limits of the modal class in parts of a unit;

$-\Delta \mathrm{T} 0,5$ - reaction time diapason at the level $0,5 \mathrm{Pmax}$ in $\mathrm{s}$;

- T0,5 - reaction time value that corresponds to the middle of the diapason $\Delta \mathrm{T} 0,5$ in $\mathrm{s}$.

The obtained results allow to calculate the following characteristics of the brain GFS: functional system level (FSL), reaction stability (RS), functional possibilities level (FPL). These parameters in conventional units (c.u.) are calculated by the formulas:

$$
\begin{aligned}
& \Phi P C=\ln 1 / \mathrm{Tmod}^{*} \Delta \mathrm{T} 0,5 ; \\
& \mathrm{CP}=\ln \mathrm{Pmax} / \Delta \mathrm{T} 0,5 ; \\
& \mathrm{P} \Phi \mathrm{M}=\ln \mathrm{Pmax} / \Delta \mathrm{T} 0,5 * \mathrm{~T} 0,5 .
\end{aligned}
$$

SFL characterizes the strain of tonic non-specific influences. The more SFL, the higher CNS functional level is. RS reflects the degree of the nervous system functional state stability. The more reaction stability parameter, the less reaction time dissipation is. FPL allows to assess the brain ability to form the high functional level and to keep it steadfastly.

The well-known methods of the brain general functional state assessment by T.D. Loskutova provides the necessity of the equipment complex of 3-4 blocs, with mass up to $20 \mathrm{~kg}$ that narrows its practical use. The repeated researches that take 30 and more seconds naturally decrease psychophysiological possibilities of a researcher. At the same time the analysis and processing of obtained data are usually realized by hand that needs much time (1-1,5 hours), doesn't exclude incorrectness, doesn't provide the current and efficient assessment of the brain GFS.

In the laboratory of age sport physiology of the department of biology and health bases of SNPU, named after K.D. Ushinsky were developed, produced and probated the devices "Flash" and more perfect "AVRBOSH-1" [11], that provide the program management and realization of a test, automated registration of 60 values of the latent period of a simple reaction, with their further transmission to a computer and results analysis. "AVR-BOSH-1" realizes these processes independently with the visual indication of characteristics on a monitor.

The examination method is realized as following: an examined person presses a button by the thumb of the "working" hand as fast as possible as a response to light irritants. A reaction time is reflected on an indicator of a researcher, registered and memorized. A series consists of 60 signals, an interval between them varies within the diapason 3-6 seconds to avoid a reflex production for some time. The test duration is up to 6 minutes. According to data of the latent period of a visual-motor reaction is built the graph of LP values distribution that characterizes the individual level of the brain GFS, values of its three parameters- system functional level (SFL), reaction stability (RS), functional possibilities level (FPL), values of $60 \mathrm{LP}$ - are also printed. Examination reports are the results.

The testing was carried out in the state of the relative muscular rest and at the fifth minute of restoration after a physical load by the closed cycle, set on a veloergometer (according to D.M. Davidenko's method [12]): at the beginning the load intensity grew with the speed $33 \mathrm{~W} / \mathrm{min}$ up to the pulse frequency $150-155$ strokes in a minute, then decreased to null with the same speed.

\section{Results of research and their discussion}

According to initial values of RS, SFL, FPR, examined persons may be divided in three main groups, despite their age and research conditions [10] - with the low, middle and high functional level of the central nervous system. Differences are observed by the percent ratio of examined persons in groups.

Analyzing the obtained results, we based ourselves on the norms, elaborated by T. D. Loskutova (table 1).

The parameters of GFS of the brain of first year students were in the middle level diapason (at that $\mathrm{CV}$ varied from 5,95 to $25,45 \%$ ). But individual values were distributed unequally (Fig. 1).

Table 1

Criteria of the assessment of the general functional state of the brain of healthy adults (according to T.D. Loskutova [10])

\begin{tabular}{|c|c|c|c|c|c|c|c|}
\hline \multirow{2}{*}{ Criteria } & \multicolumn{3}{|c|}{ Norm levels } & \multicolumn{4}{c|}{ Shifts degrees at pathology } \\
\cline { 2 - 7 } & high & middle & low & I & II & III & IV \\
\hline SFL, c.u. & $4,9-5,5$ & $4,5-4,9$ & $4,2-4,5$ & $3,8-4,2$ & $2,9-3,8$ & $1,0-2,9$ & Less than 1,0 \\
\hline RS, c.u. & $2,0-2,8$ & $1,5-2,0$ & $1,0-1,5$ & $0,5-1,0$ & $-0,7-0,5$ & $-3,3-0,7$ & Less than $-3,3$ \\
\hline FPL, c.u. & $3,8-4,8$ & $3,1-3,8$ & $2,7-3$ & $2,0-2,7$ & $0,4-0,2$ & $-2,7-0,4$ & Less than $-2,7$ \\
\hline
\end{tabular}



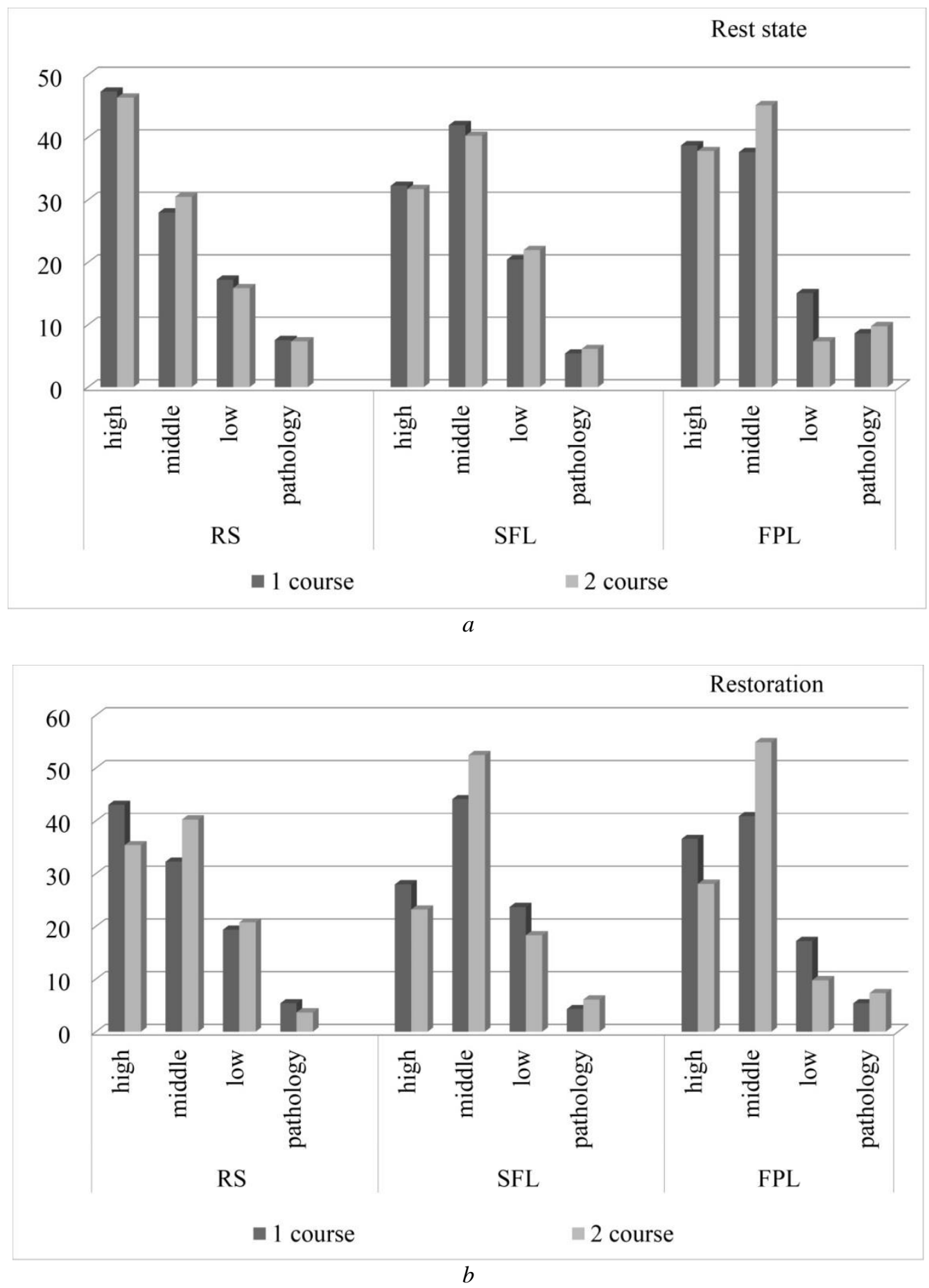

Fig.1. The levels of the brain general functional state of first year students of the physical education department: $a$ - state of the relative muscular rest; $b$ - fifth minute of restoration after a physical load

Thus, for example, indices of the CNS initial functional state of first year students testified that in $48 \%$ of young people the reaction stability was high, in $28 \%$ - middle and in $17 \%$ - low. The system functional level in $32 \%$ of cases was characterized as high, in $42 \%$ - as middle and in $21 \%$ - as low. Analogously, students were distributed by the functional possibilities level as following: FPL in $39 \%$ of examined persons was high, in $38 \%$ - middle, in $15 \%$ - low.

It is necessary to note, that according to T. D. Loskutova's scale, in several persons was observed the pathological level of the brain GFS by all parameters: $7 \%$ by the reaction stability, $5 \%$ - by the system functional level and $7 \%$ - by the functional possibilities lev- el. According to T. D. Loskutova's method, the pathological level is registered only under conditions of the indices decrease. In the research were revealed the case of the criteria rise beyond the given diapasons that indicates the necessity to consider them also as a pathological reaction, detected in $2 \%$ of students by the reaction stability and functional possibilities level. It testifies to the fact that it is necessary to review methodical approaches as to the brain GFS assessment.

The indices of second year students were distributed in the other way. By the reaction stability $46 \%$ of cases corresponded to the high level, $31 \%$ - to the middle and $16 \%$ - to the low one. Values of the system functional level were registered by high values in $32 \%$, 
by middle - in $40 \%$, by low - in $22 \%$ of students. The functional possibilities level in $38 \%$ of young people was assessed as high, in $45 \%$ - as mean, in $7 \%$ - as low. In examined persons of this group were also observed pathological cases, but to the side of decrease, as opposite to first year students. Only in $1 \%$ of young people was registered a pathology to the side of increase of results by the reaction stability.

There were established two main types of the dynamics of GFS indices of the brain of young people at a dosed load with a reversion that differ by the directionality, changes depth and quantitative ratio (Fig. 2).

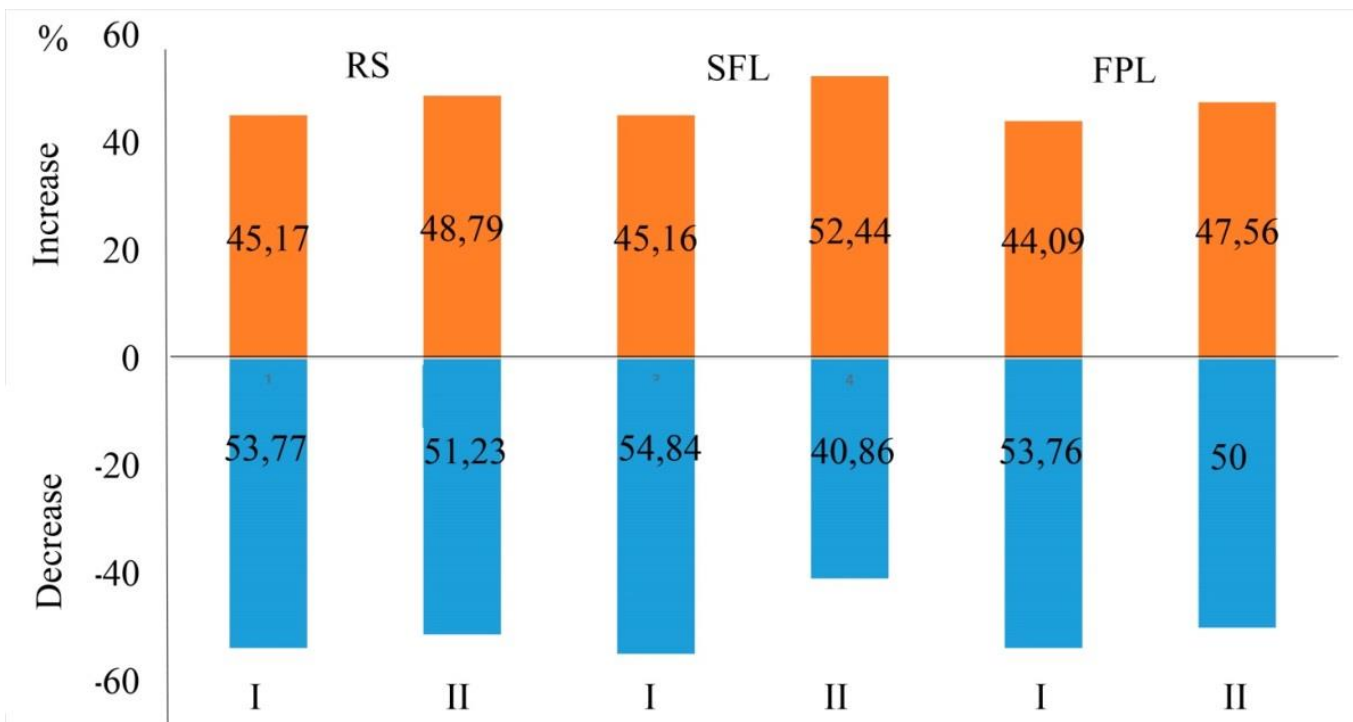

Fig. 2. The changes of the indices of the brain general functional state in first and second year students of the physical education faculty after a physical load: RS - reaction stability; SFL - system functional level;

FPL - functional possibilities level; I - first year students; II - second year students

The dependence of post-working changes of the brain GFS on initial values is demonstrated: at the high GFS level usually takes place the decrease of the indices
(Fig. 3), at low initial values the increase of the brain GFS criteria takes place (Fig. 4).

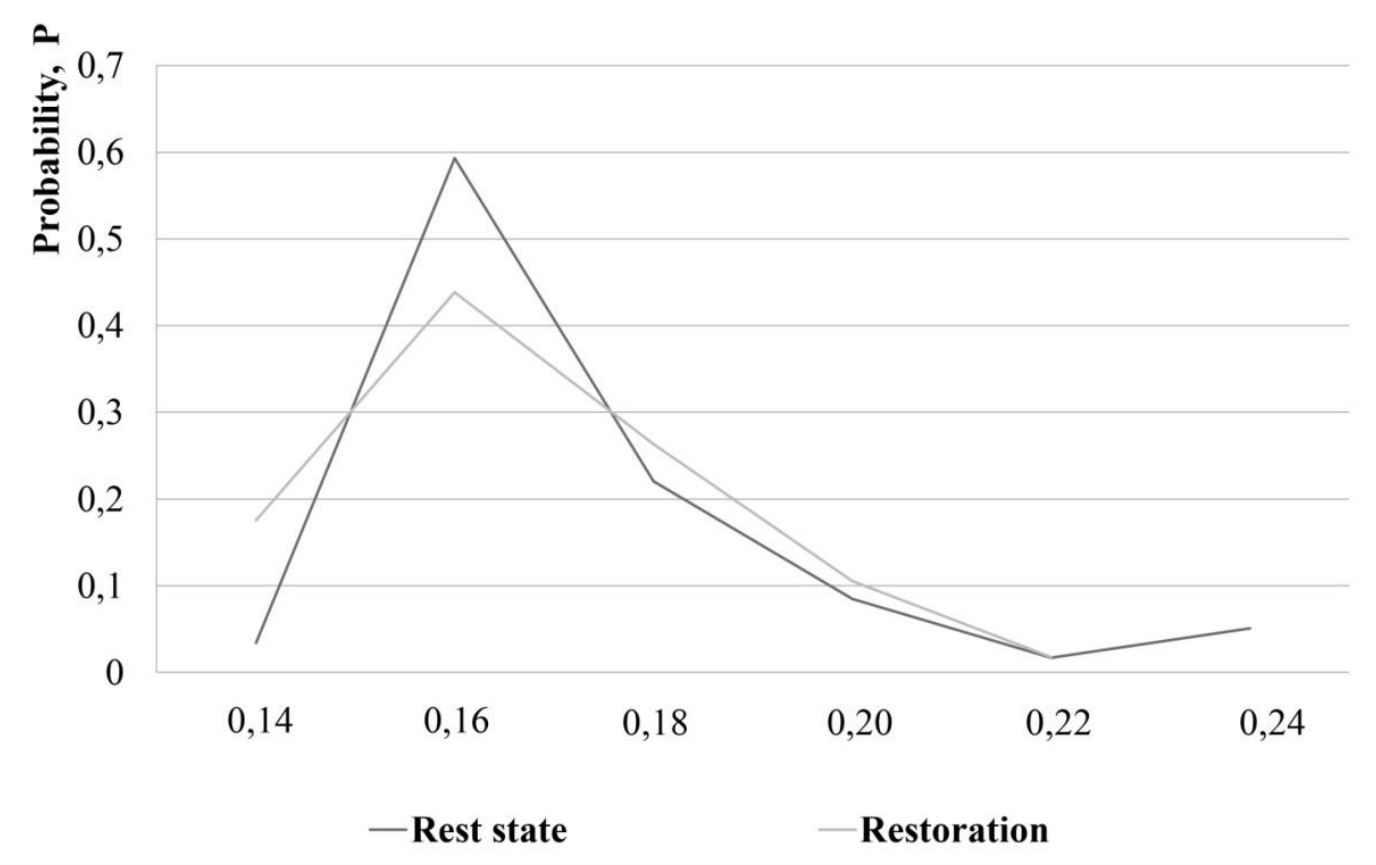

Fig. 3. The histogram of the reaction time distribution at the high initial level of the general functional state of the nervous system (rest state: SFL - 5,19; RS - 2,55; FPL - 4,4; restoration phase: SFL - 5,04, RS - 2,25, FPL - 4,12) 


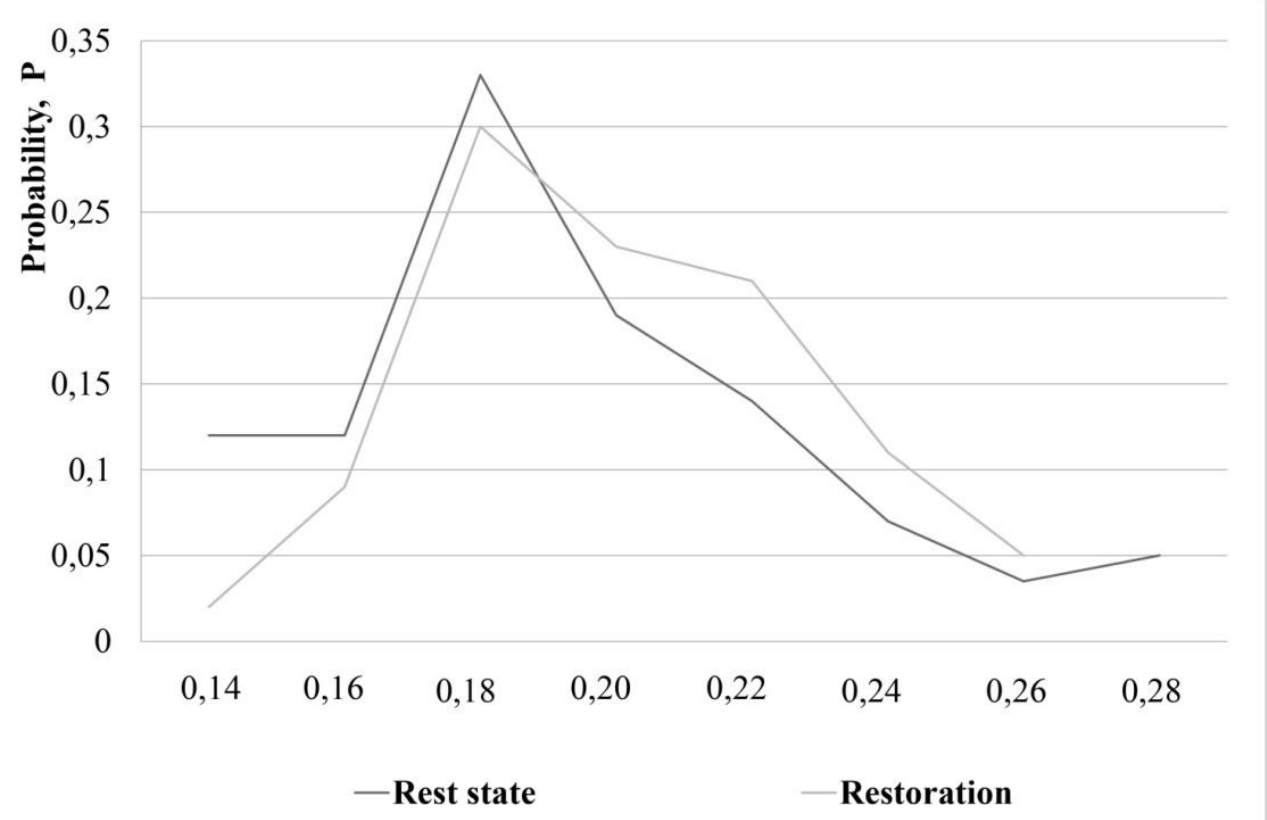

Fig. 4. The histogram of the reaction time distribution at the low initial level of the general functional state of the nervous system (rest state: SFL-4,35, SR - 1,29, FPL - 2,88; restoration phase: SFL - 4,18, SR - 1,21, FPL - 2,81)

The revealed features are agreed and prove previously noted regulations of the brain GFS reaction in the wide spectrum of examined persons to intellectual and dosed and maximal muscular loads. So, the dynamics of CNS parameters corresponds to the "pendulum" law that covers a series of other systems and indices (Fig. 2). As the third type of the brain GFS reaction to physical and intellectual loads must be considered the absence of oneor multi-directed change of its parameters that is estimated as the system rigidity and inadequate reacting.

In persons with the high brain CNS the curve of the time distribution of a simple visual-motor reaction was characterized by the single top, narrow base, high percent of equal values, graph shift to the left, to the side of small values of reactions time (Fig. 3). At the low GFS level of the brain, on the contrary, the curve had many tops, wide base, low and shifted to the right - to the side of high values of reactions (Fig. 4).

As it has been demonstrated earlier [13], the established reaction types have the universal character and are observed in representatives of different age, sex, physical preparedness under the influence of dosed and maximal muscular and also intellectual loads. In this connection the central nervous system reaction must be assessed by the diapason of deviations (Table 2) from the initial level: indices shift within $\pm 25 \%$ must be considered as an activation reaction, within $\pm 50 \%$ - as a strain reaction, and fluctuations over $50 \%$ - as a pre-pathology with the possible transfer to the disease state [14].

Table 2

The diapason of deviations of the initial level of GFS indices of second and first year students of the physical education faculty

\begin{tabular}{|c|c|c|c|c|c|c|}
\hline \multirow{2}{*}{ Shift, \% } & \multicolumn{2}{|c|}{ RS } & \multicolumn{2}{c|}{ SFL } & \multicolumn{2}{c|}{ FPL } \\
\cline { 2 - 7 } & 1 year, $\%$ & 2 year, $\%$ & 1 year, \% & 2 year, $\%$ & 1 year, $\%$ & 2 year, $\%$ \\
\hline $\pm 25 \%$ & 65,59 & 64,64 & 86,02 & 93,60 & 97,84 & 81,70 \\
\hline $\pm 50 \%$ & 21,51 & 23,17 & 11,83 & 0 & 0 & 14,64 \\
\hline $\pm 75 \%$ & 7,53 & 8,54 & 2,15 & 0 & 0 & 1,22 \\
\hline Over $75 \%$ & 4,30 & 3,65 & 0 & 0 & 0 & 0 \\
\hline No changes & 1,07 & 0 & 0 & 6,40 & 2,16 & 2,44 \\
\hline
\end{tabular}

It is agreed with the conclusions by Zimkina A.M. that cerebral homeostasis disorders can take place by the following characteristics: shifts of excitability, lability and reactivity levels, fluctuations of these indices by physiological limits, extreme stability of the functional level, slow renewal and dissociation of regulating systems [15].

Such approach gives an objective individual characteristic to adaptive reactions of the central nervous system to physical and intellectual loads and, possibly, to other factors.

\section{Conclusions}

1. The realized studies of the dynamics of the functional state of the central nervous system of first and second year students of the physical education faculty, by data of a simple visual-motor reaction (by T. D. Loskutova) allowed to separate three main levels of the brain functional state. In the state of the relative muscular rest according to the system functional level criteria the high level corresponded to $38-48 \%$ of first year students, the middle level included $28-42 \%$, low $-15-21 \%$ of cases. The results of the study of second year students didn't re- 
liably differ and included correspondingly 32-46, 31-48 and 7-22 percents.

2. Under the influence of a dosed physical veloergometric load by the closed cycle were observed two main reaction types of the general functional state of the young people's brain, characterized by the different directionality (increase, decrease), shifts depth, quantitative ratio and their dependence on the initial state. The high initial level of GFS conditions the decrease, the low one, on the contrary, provides the increase of its criteria after the influence of external factors. The lower percent of shifts to the decrease of the CNS functional state criteria was registered in second year students, but the more percent of cases was observed to the side of increase.

3. A reaction of the students' central nervous system to external effects as dosed physical loads by the closed cycle must be assessed by the diapason of deviations from the initial level by the "pendulum" law: indices shifts within $\pm 25 \%$ must be considered as an activation reaction, within $\pm 50 \%$ - as a strain reaction, and fluctuation over $\pm 50 \%$ - as a pre-pathology with a possible transfer into the disease state.

\section{References}

1. Agadzhanyan, H. A. Kachestvo i obraz zhizni studencheskoy molodezhi [Text] / N. A. Agadzhanyan, I. V. Radysh // Ekologiya cheloveka. - 2009. - Vol. 5. - P. 3-8.

2. Kaznacheev, V. P. Sovremennye aspekty adaptatsii [Text] / V. P. Kaznacheev. - Novosibirsk: Nauka, 1980. - 192 p.

3. Makarenko, M. V. Funktsionalnyi stan tsentralnoi nervovoi systemy za umov pererobky informatsii riznoho stupenia skladnosti u osib z riznym rivnem rukhlyvosti nervovykh protsesiv [Text] / M. V. Makarenko, V. S. Lyzohub, Yu. O. Petrenko, T. A. Bibik, O. E. Yavnyk, L. I. Yukhymenko // Fiziolohichnyi zhurnal. - 2002. - Vol. 48, Issue 1. - P. 9-14.

4. Shcherbatyh, Yu. V. Samoregulyatsiya vegetativnogo gomeostaza pri emotsional'nom stresse [Text] / Yu. V. Shcherbatyh // Fiziologiya cheloveka. - 2000. - Vol. 26, Issue 5. - P. 151-152.

5. Meerson, F. Z. Adaptatsiya k stressornym situatsiyam i fizicheskim nagruzkam [Text] / F. Z. Meerson, M. G. Pshennikova. Moscow: Meditsina, 1988. - 256 p.

6. Anokhin, P. K. Ocherki po fiziologii funktsional'nyh sistem [Text] / P. K. Anokhin. - Moscow: Meditsina, 1975. - 448 p.

7. Bayguzhin, A. P. Faktory rezul'tativnosti psihofiziologicheskogo issledovaniya funktsional'nogo sostoyaniya tsentral'noy nervnoy sistemy u studentov [Text] / A. P. Bayguzhin // Vestnik YUUrGU. Seriya «Obrazovanie, zdravoohranenie, fizicheskaya kul'tura». - 2011. - Vol. 26. - P. 131-135.

8. Belenko, I. S. Psihofiziologicheskie osobennosti u yunyh sportsmenov igrovyh vidov sporta raznogo vozrastnogo perioda razvitiya i trenirovannosti [Text] / I. S. Belenko // Vestnik TGPU. - 2009. - Vol. 3 (81). - P. 54-58.

9. Dobrostan, O. V. Psykhofiziolohichni osoblyvosti adaptatsii pershokursnyts z riznym indeksom masy tila [Text]: mat. V Vseukr. nauk.-prakt. konf. / O. V. Dobrostan, O. I. Pliska // Indyvidualni psykhofiziolohichni osoblyvosti liudyny ta profesiina diialnist. - Cherkasy, 2014. - P. 32.

10. Loskutova, T. D. Funktsional'noe sostoyanie tsentral'noy nervnoy sistemy i ego otsenka po parametram prostoy dvigatel'noy reaktsii [Text]: avtoref. dis. ... kand. med. nauk / T. D. Loskutova. - Leningrad, 1977. - 24 p.

11. Pat. No. 20869 UA. Prystrii dlia diahnostyky funktsionalnoho stanu mozku liudyny «Molnyia». MPK: A61B 5/103, A61B 5/16 [Text] / Bosenko A. I., Shumeiko K. P. - No. u2006093326; declareted: 28.06.2006; published: 15.02.2007; Bul. No. 2. - 6 p.

12. Davidenko, D. N. Metodika otsenki mobilizatsii funktsional'nyh rezervov organizma po ego reaktsii na dozirovannuyu nagruzku [Text] / D. N. Davidenko // Nauchno-teoreticheskiy zhurnal «Uchenye zapiski universiteta imeni P. F. Lesgafta». - 2011. Vol. 12 (70). - P. 52-57.

13. Bosenko, A. I. Vyyavlenie funktsional'nyh vozmozhnostey serdechno-sosudistoy i tsentral'noy nervnoy sistem u podrostkov pri napryazhennoy myshechnoy deyatel'nosti [Text]: avtoref. dis. ... kand. biol. nauk. / A. I. Bosenko. - Tartu, 1986. -25 p.

14. Baevskiy, R. M. Otsenka adaptativnyh vozmozhnostey organizma i risk razvitiya zabolevaniy [Text] / R. M. Baevskiy, A. P. Berseneva. - Moscow: Meditsina, 1997. - 236 p.

15. Zimkina, A. M. Neyrofiziologicheskie issledovaniya v ekspertize trudosposobnosti [Text] / A. M. Zimkina, V. I. Klimova-Cherkasova, A. G. Povorinskiy; A. M. Zimkina, V. I. Klimova-CHerkasova (Eds.). - Leningrad: Meditsina, 1978. - 280 p.

Рекомендовано до публікації д-р біол. наук, професор Галкін Б. М. Дата надходження рукопису 29.05.2017

Anatolii Bosenco, PhD, Associate Professor, Head of Department, Department of Biology and Health Care, State Institution «South Ukrainian National Pedagogical University named after K. D. Ushynsky», Staroportofrankivska str., 26, Odesa, Ukraine,

E-mail: bosenco@ukr.net

Maria Topchii, Postgraduate student, Department of Biology and Health Care, State Institution «South Ukrainian National Pedagogical University named after K. D. Ushynsky», Staroportofrankivska str., 26, Odesa, Ukraine, 65020

E-mail: topciy_maria@ukr.net 